\title{
Efektivitas Penggunaan Media Alat Peraga Terhadap Tingkat Pemahaman Siswa pada Materi Sistem Ekskresi di SMA Negeri 1 Watopute
}

\author{
Munawar'; Jumarddin La Fua²; Abdul Kadir² ${ }^{2}$ Halmuniati $^{2}$ \\ 1) Alumni Prodi Tadris Biologi, Fakultas Tarbiyah dan Ilmu Keguruan (FTIK), Institut Agama Islam Negeri \\ (IAIN) Kendari; \\ 2) Dosen FTIK, IAIN Kendari. \\ Email Korespondensi: jumarddinlafua@gmail.com
}

\begin{abstract}
This article was aims to determine the level of understanding of students after using teaching aids media and without using teaching aids media. This type of research is quantitative research, with a quasi-experimental method. Data analysis techniques were performed using descriptive statistical analysis. The location of research in SMA Negeri 1 Watopute with the research sample is class XI MIA 2 (experimental class) and class XI MIA 4 (control class), which was obtained by purposive random sampling technique. The results of this study indicate that students' understanding after using teaching aids media was higher than without using teaching aids media, and the use of teaching aids media effectively increases student understanding. The use of teaching aids media in the learning process can attract students' attention and make students motivated and actively involved in the learning process, easier to remember, tell and understand the material in a concrete manner. In addition, students can also master the material learning so they get better learning outcomes.
\end{abstract}

Keywords: Teaching aids media, student's level of understanding

\begin{abstract}
ABSTRAK
Artikel ini bertujuan untuk mengetahui tingkat pemahaman siswa sesudah menggunakan media alat peraga dan tanpa menggunakan media alat peraga. Jenis penelitian ini adalah penelitian kuantitatif, dengan metode quasi eksperimen. Teknik analisis data dilakukan dengan menggunakan analisis statistik deskriptif. Lokasi penelitian di SMA Negeri 1 Watopute dengan sampel penelitian yaitu kelas XI MIA 2 (kelas eksperimen) dan kelas XI MIA 4 (kelas kontrol), yang diperoleh dengan teknik pengambilan sampel secara purposive random sampling. Hasil penelitian ini menunjukkan bahwa pemahaman siswa sesudah menggunakan media alat peraga lebih tinggi dibandingkan dengan tanpa menggunakan media alat peraga, dan penggunaan media alat peraga efektif meningkatkan pemahaman siswa. Penggunaan media alat peraga dalam proses pembelajaran dapat menarik perhatian siswa dan membuat siswa termotivasi serta terlibat aktif dalam proses pembelajaran, lebih mudah mengingat, menceritakan dan memahami materi secara konkret. Selain itu, siswa juga dapat menguasai materi sehingga mendapatkan hasil belajar yang lebih baik.
\end{abstract}

Kata kunci: Media alat peraga, tingkat pemahaman siswa

\section{PENDAHULUAN}

Kurikulum 2013 menyatakan bahwa guru berperan sebagai fasilitator dan membantu siswa dalam menemukan fakta, konsep atau prinsip bagi diri siswa dengan pendekatan student center bukan lagi dengan pendekatan teacher center. Guru sebagai fasilitator dalam proses pembelajaran dituntut untuk dapat memiliki dan menggunakan berbagai alat bantu mengajar (media) yang sesuai dengan kebutuhan guna meningkatkan kualitas pembelajaran. Penggunaan media pembelajaran secara tidak langsung dapat mempengaruhi semangat serta ketertarikan siswa dalam mengkuti kegiatan pembelajaran. Ketertarikan dan semangat siswa dalam proses pembelajaran diharapkan dapat meningkatkan kualitas pembelajaran sehingga hasil yang diperoleh sesuai dengan yang diharapkan (Henulili, dkk., 2009). Kehadiran media dalam kegiatan pembelajaran dapat memperjelas materi yang disampaikan dan kerumitan materi dapat disederhanakan sehingga materi pembelajaran dapat diterima dan dipahami oleh siswa secara maksimal (Djamaral dan Zain, 2010). Media alat peraga pembelajaran digunakan sebagai sumber belajar dapat meningkatkan kualitas pembelajaran yang berlangsung serta dapat meningkatkan aktivitas, motivasi, dan hasil belajar siswa.

Salah satu yang perlu diperhatikan dalam melakukan kegiatan pembelajaran adalah motivasi belajar siswa. Siswa yang kurang berprestasi bukan disebabkan kemampuannya yang kurang, tetapi karena tidak adanya motivasi untuk belajar sehingga siswa tidak berusaha untuk mengarahkan segala kemampuannya (Sanjaya, 2006). Pencapaian kualitas hasil pendidikan yang memadai bukan hanya menuntut guru untuk dapat mewujudkan seperangkat peran dan tugas yang diembannya tetapi juga ditentukan oleh perilaku kreatif dalam proses pebelajaran. Kreativitas guru merupakan hal penting dalam proses pembelajaran, menjadi gerbang utama dalam upaya meningkatkan pencapaian hasil belajar. Kreativitas guru tersebut dapat diwujudkan berdasarkan kemampuannya untuk memperhatikan dan memahami prinsip-prinsip belajar siswa meliputi pemberian perhatian 
dan motivasi (Agung, 2010), sehingga untuk meningkatkan motivasi dan pemahaman siswa diperlukan penggunaan media alat peraga dalam proses pembelajaran. Media alat peraga merupakan salah satu media objek pembelajaran yang menggambarkan peristiwa, fenomena, dan mekanisme kerja suatu benda. Pemakaian media alat peraga dalam proses pembelajaran dapat membangkitkan minat dan keinginan yang baru, membangkitkan motivasi dan rangsangan kegiatan belajar sehingga siswa tidak merasa bosan dalam meraih tujuan-tujuan belajar (Saleh, dkk., 2015).

Media alat peraga telah belum pernah diterapkan di SMA Negeri 1 Watopute, Kabupaten Muna, Sulawesi Tenggara. Selama ini, sekolah tersebut hanya menggunakan media pembelajaran sebatas media power point. Selain itu, penelitian tentang penggunaan media alat peraga telah banyak dilakukan seperti pengaruh penggunaan alat peraga dari bahan bekas tentang sistem eredaran darah manusia terhadap hasil belajar biologi siswa kelas XI SMAN 7 kota Kupang tahun 2014 (Nomleni dan Merukh, 2014), efektivitas penggunaan alat peraga kodama dalam mengerjakan soal matematika materi persamaan garis lurus (Ahmad, 2017), pengembangan alat peraga circulatori bottle untuk meningkatkan pemahaman konsep siswa kelas VIII SMP pada materi sistem peredaran darah manusia (Imansnuna, dkk., 2016). Hal ini mengisyaratkan bahwa penggunaan media belajar berupa alat peraga sangat berpengaruh terhadap kegiatan pembelajaran. Namun berbeda dengan penelitian yang dilakukan beberapa penelitian tersebut, penelitian ini lebih menekankan kepada keterlibatan siswa dalam proses pembelajaran dengan penggunaan media, bertujuan agar siswa dapat termotivasi dalam mengikuti proses pembelajaran serta dapat memahami materi dan memperoleh hasil belajar yang maksimal.

\section{METODE PENELITIAN}

Penelitian ini dilakukan dengan pendekatan kuantitatif metode quasi eksperimen yang digunakan untuk mencari pengaruh perlakuan tertentu terhadap yang lain dalam kondisi yang terkendalikan. Penelitian ini diilakukan di SMA Negeri 1 Watopute Kabupaten Muna Sulawesi Tenggara. Populasi dalam penelitian ini adalah seluruh siswa kelas XI MIA SMA Negeri 1 Watopute. Teknik penetuan sampel secara purposive yaitu berdasarkan tujuan-tujuan tertentu yang telah ditetapkan serta mewakili karakteristik dari populasi, dan pengambilan sampel secara simple random yaitu pengambilan sampel secara acak dimana pengambilan sampel memberikan peluang yang sama bagi setiap unsur (anggota) populasi untuk dipilih menjadi anggota sampel. Variabel dalam penelitian ini terdiri dari variabel bebas yaitu penggunaan media alat peraga dan variabel terikat yaitu tingkat pemahaman siswa. Desain penelitian yang digunakan adalah posttest control group design yaitu desain eksperimen yang dilakukan dengan melakukan pengukuran atau penilaian sesudah perlakuan pada kelas eksperimen dan kelas kontrol (Winarno, 2011). Instrumen penelitian dan teknik pengumpulan data dalam penelitian ini yaitu melalui tes dan dokumentasi. Teknik analisis data yang digunakan dalam penelitian ini yaitu analisis statistik deskriptif, yang digunakan untuk menganalisis data dengan cara mendeskripsikan data yang telah terkumpul tanpa menarik kesimpulan atas populasi yang diamati. Teknik analisis deskriptif dilakukan dengan mencari nilai rata-rata dan standar deviasi.

\section{HASIL PENELITIAN}

Data hasil belajar siswa sesudah menggunakan media alat peraga pada kelas eksperimen dan tanpa menggunakan media alat peraga pada kelas kontrol, yang diperoleh dari tes hasil belajar biologi siswa. Tes diberikan kepada siswa sesudah menggunakan media alat peraga dan tanpa menggunakan media alat peraga. Distribusi data hasil belajar siswa sesudah perlakuan disajikan pada tabel 1 berikut.

Tabel 1. Distribusi Frekuensi Tingkat Pemahaman Siswa Sesudah Media Alat Peraga Pada Kelas Eksperimen dan Tanpa Menggunakan Media Alat Peraga pada Kelas Kontrol

\begin{tabular}{|c|c|c|c|c|c|c|}
\hline \multirow{2}{*}{ No } & \multicolumn{3}{|c|}{ Kelas Eksperimen } & \multicolumn{3}{c|}{ Kelas Kontrol } \\
\cline { 2 - 7 } & Interval & Frekuensi & \% & Interval & Frekuensi & Persentase (\%) \\
\hline 1 & $80-82$ & 8 & 28,57 & $80-81$ & 7 & 26,92 \\
\hline 2 & $83-85$ & 8 & 28,57 & $82-83$ & 8 & 30,77 \\
\hline 3 & $86-88$ & 3 & 10,71 & $84-85$ & 5 & 19,23 \\
\hline 4 & $89-91$ & 2 & 7,14 & $86-87$ & 2 & 7,69 \\
\hline 5 & $92-94$ & 2 & 7,14 & $88-89$ & 2 & 7,69 \\
\hline 6 & $95-97$ & 3 & 10,71 & $90-91$ & 2 & 7,69 \\
\hline 7 & $98-100$ & 2 & 7,14 & & & \\
\hline
\end{tabular}

Pada tabel 1 menunjukkan bahwa tingkat pemahaman siswa sesudah menggunakan media alat peraga frekuensi tertinggi terletak pada nilai interval 80-82 dan interval 83-85 dengan jumlah siswa masing-masing sebanyak 8 orang dengan perolehan persentase masing-masing sebesar $28,57 \%$ dan frekuensi terendah berada pada nilai interval 89-91, interval 92-94 dan interval 98-100 dengan jumlah siswa masing-masing sebanyak 2 
orang siswa dengan perolehan persentase masing-masing sebesar 7,14\%. Sedangkan tingkat pemahaman siswa sesudah tanpa menggunakan media alat peraga frekuensi tertinggi berada pada interval 82-83 sebanyak 8 orang dengan perolehan persentase sebesar $30,77 \%$ dan frekuensi terendah berada pada nilai interval 86-87, interval 88-89, dan interval 90-91 dengan jumlah siswa masing-masing sebanyak 2 orang dengan perolehan persentase masing-masing sebesar 7,69\%. Secara jelas distribusi frekuensi hasil belajar siswa sesudah menggunakan media alat peraga dan tanpa menggunakan media alat peraga disajikan dalam bentuk gambar 1 berikut.

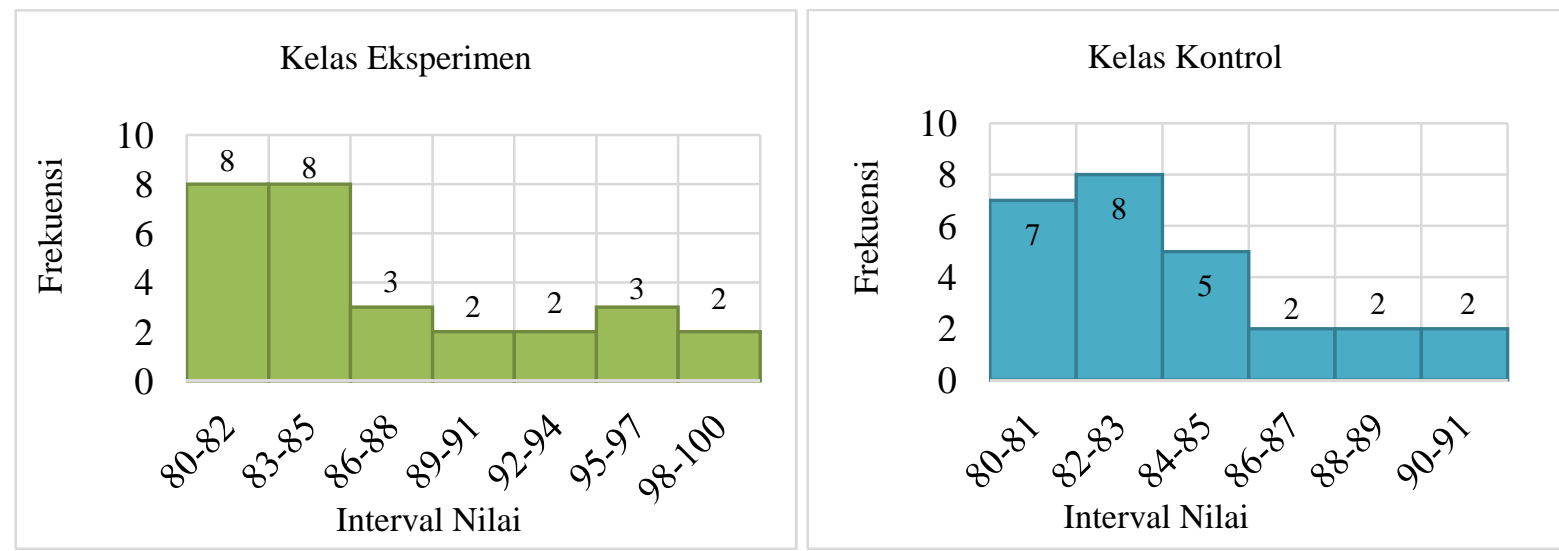

\section{Gambar 1. Distribusi Frekuensi Tingkat Pemahaman Siswa Sesudah Menggunakan Media Alat Peraga Pada Kelas Eksperimen dan Tanpa Menggunakan Media Alat Peraga Pada Kelas Kontrol}

Berdasarkan gambar 1 menggambarkan bahwa tingkat pemahamana siswa dilihat dari nilai frekuensi tertinggi, sesudah menggunakan media alat peraga pada kelas eksperimen lebih tinggi yaitu dengan nilai intervai 80-82 dan interval 83-85 dibandingkan dengan sesudah tanpa menggunakan media alat peraga pada kelas kontrol dengan nilai interval 82-83. Sedangkan dilihat dari nilai frekuensi terendah, sesudah menggunakan media alat peraga pada kelas eksperimen lebih tinggi yaitu dengan nilai intervai 89-91, interval 92-94 dan interval 98-100 dibandingkan dengan sesudah tanpa menggunakan media alat peraga pada kelas kontrol dengan nilai interval 8687, interval 88-89, dan interval 90-91. Untuk melihat nilai rata-rata hasil belajar siswa sesudah menggunakan media alat peraga dan tanpa menggunakan media alat peraga disajikan pada tabel berikut.

Tabel 2. Rata-rata Tingkat Pemahaman Siswa Sesudah Menggunakan Media Alat Peraga Pada Kelas Eksperimen dan Tanpa Menggunakan Media Alat Peraga Pada Kelas Kontrol

\begin{tabular}{|c|l|c|c|}
\hline No & \multicolumn{1}{|c|}{ Statistik } & Kelas Eksperimen & Kelas Kontrol \\
\hline 1 & Nilai tertinggi & 100 & 91 \\
\hline 2 & Nilai terendah & 80 & 80 \\
\hline 3 & Rata-rata & 86,89 & 83,73 \\
\hline 4 & Standar deviasi & 5,96 & 3,07 \\
\hline
\end{tabular}

Pada tabel 2 menunjukkan bahwa tingkat pemahaman siswa sesudah menggunakan media alat peraga memiliki nilai tertinggi sebesar 100 , nilai terendah sebesar 80 , dan nilai rata-rata sebesar 86,89 lebih tinggi dibandingkan dengan hasil belajar siswa sesudah tanpa menggunakan media alat peraga memiliki nilai tertinggi sebesar 91, nilai terendah sebesar 80, dan nilai rata-rata sebesar 83,73.

\section{PEMBAHASAN}

Memahami adalah mengetahui tentang sesuatu dan dapat melihatnya dari berbagai segi. Seorang peserta didik dikatakan memahami apabila ia dapat memberikan penjelasan atau memberi uraian lebih rinci tentang hal itu dengan menggunakannya kata-kata sendiri (Sudijono, 2009). Siswa dapat dikatakan memahami secara relasional jika siswa sudah mampu menerapkan dengan tepat suatu ide yang bersifat umum pada hal-hal yang khusus atau situasi baru, dan siswa dapat dikatakan memahami secara formal apabila siswa mampu menguraikan suatu masalah menjadi bagian-bagian yang lebih rinci serta mampu memahami hubungan antar bagian-bagia tersebut (Hasan, 2012).

Hasil penelitian tingkat pemahaman siswa sesudah menggunakan media alat peraga mayoritas siswa berada pada nilai interval 80-82 dan interval 83-85 dengan jumlah siswa masing-masing sebanyak 8 siswa sedangkan pada kelas kontrol sesudah tanpa menggunakan media alat peraga mayoritas siswa berada pada nilai nterval 82-83 sebanyak 8 siswa. Berdasarkan nilai interval tersebut menunjukkan bahwa tingkat pemahaman siswa di kelas eksperimen lebih tinggi dibandingkan dengan kelas kontrol. Tingginya tingkat pemahaman siswa 
pada kelas eksperimen disebabkan adanya penggunaan media alat peraga merangsang pola pikir siswa karena melalui media alat peraga materi dapat diperjelas agar tidak verbalistik yang kemudian membuat siswa mampu mengingat dan memahami materi yang sedang dipelajari. Hal ini sejalan dengan pendapat Arsyad bahwa pemakaian media pembelajaran dalam proses pembelajaran dapat mebangkitkan keinginan dan rangsangan kegiatan belajar pada siswa (Arsyad, 2007). Demikian juga dengan penelitian yang dilakukan oleh Syarah bahwa penggunaan alat peraga merupakan kategori enactive yang dapat memfasilitasi siswa untuk melakukan simulasi dan memperjelas penyajian materi serta memberikan perangsangan yang sama dan persepsi yang sama sehingga membantu siswa untuk mengingat dengan lebih baik (Syarah 2016).

Hasil penelitian pada kelas eksperimen sesudah menggunakan media alat peraga diperoleh nilai ratarata sebesar 86,89 sedangkan pada kelas kontrol sesudah tanpa menggunakan media alat peraga diperoleh nilai rata-rata sebesar 83,73. Berdasarkan hasil tersebut tingkat pemahaman siswa menggunakan media alat peraga pada kelas eskperimen lebih tinggi dibandingkan dengan tanpa menggunakan media alat peraga pada kelas kontrol. Hal ini sejalan dengan penelitian yang dilakukan Hapsoro bahwa pemahaman siswa terhadap konsep akan menjadi lebih baik ketika siswa melakukan aktivitas konseptual, yaitu siswa menemukan konsep dari aktivitas memecahkan masalah (Hapsoro dan Susanto, 2011). Demikian juga dengan menurut ennis yang dikutip oleh Hartati bahwa peningkatan hasil belajar dipengaruhi oleh adanya perubahan cara berpikir kritis yang masuk akal berdasarkan nalar yang difokuskan untuk menentukan apa yang harus diyakini dan dilakukan peserta didik (Hartati, 2010).

Tingginya tingkat pemahaman siswa pada kelas eksperimen dibandingkan dengan kelas kontrol tidak terlepas dari penggunaan media alat peraga dalam proses pembelajaran. Dengan penggunaan media alat peraga membuat siswa lebih mudah mengingat, menceritakan dan memahami materi pelajaran secara konkret dapat mengurangi verbalisme, dan siswa dapat menguasai materi sehingga dapat mencapai tujuan pembelajaran. Menurut Nurfa dalam penelitiannya bahwa pembelajaran melalui kegiatan melihat, meraba dan memanipulasi obyek atau alat peraga dapat memberikan pengalaman-pengalaman nyata bagi siswa (Nurfa, dkk., 2012). Hal ini sejalan dengan penelitian yang dilakukan oleh Manzilatusita bahwa siswa dapat mencapai hasil belajar optimal jika dalam belajar siswa menggunakan sebanyak mungkin indra untuk berinteraksi dengan isi pembelajaran (Manzilatusita, 2007). Dalam hal ini media alat peraga memberikan dampak atau efek positif dalam meningkatkan pemahaman siswa. Efektivitas merupakan suatu ukuran yang menyatakan seberapa jauh target (kuantitas, kualitas dan waktu) telah tercapai, atau makin besar target yang dicapai, makin tinggi efektivitasnya (Sumantri, 2015). Pengertian efektivitas tersebut dapat disimpulkan bahwa efektivitas merupakan suatu ukuran ang menyatakan seberapa jauh target (kuantias, kualitas dan waktu) yang telah tercapai oleh manajemen, yang mana target tersebut sudah ditentukan terlebih dahulu. Hal ini dapat di padankan dalam pembelajaran seberapa jauh tujuan pembelajaran yang telah ditetapkan dapat dicapai dengan capaian kuantitas, kualitas dan waktu. Dalam konteks kegiatan pembelajaran perlu dipertimbangkan efektivitas artinya sejauhmana tujuan yang telah ditetapkan dapat dicapai sesuai harapan.

\section{KESIMPULAN}

Penggunaan media alat peraga dalam proses pembelajaran dapat menarik perhatian siswa dan membuat siswa termotivasi serta terlibat aktif dalam proses pembelajaran, lebih mudah mengingat, menceritakan dan memahami materi secara konkret dan siswa dapat menguasai materi sehingga mendapatkan hasil belajar yang lebih baik. Tingkat pemahaman siswa sesudah menggunakan media alat peraga diperoleh nilai rata-rata sebesar 86,89 lebih tinggi dibandingkan dengan tanpa menggunakan media alat peraga diperoleh nilai rata-rata sebesar 83,73 dan dengan demikian menggunakan media alat peraga efektif dapat meningkatkan pemahaman siswa.

\section{DAFTAR PUSTAKA}

Agung Iskandar (2007). Meningkatkan Kreativitas Pembelajaran Bagi Guru. Jakarta: Bestari Buana Murni.

Ahmad Herlina (2017). Efektivitas Penggunaan Alat Peraga Kodama Dalam Mengerjakan Soal Matematika Materi Persamaan Garis Lurus. Jurnal Pendidikan PEPATUDZU: Media Pendidikan dan social kemasyarakatan 13(2).

Anidityas, Nurfa Anung, Nur Rahayu Utami, dan Priyantini Widiyaningrum. (2012). Penggunaan Alat Peraga Sistem Pernapasan Manusia Pada Kualitas Belajar Siswa SMP Kelas VIII. Unnes Science Education Journal 1(2).

Arsyad, Azhar (2007). Media Pembelajaran. Jakarta: PT. RajaGrafindo Persada.

Departemen Agama (2006). Undang-undang dan Peraturan Pemerintah RI tentang Pendidikan. Direktorat Jendral Pendidikan Islam. 
Djamaral Syaiful Bahri dan Aswan Zain (2010). Strategi Belajar Mengajar. Jakarta: Rineka Cipta.

Falahudin Iwan (2014). Pemanfaatan Media Dalam Pembelajaran. Jurnal Lingkar Widyaiswara 1(4)

Hapsoro C., A., dan H., Susanto (2011). Penerapan Pembelajaran Problem Based Instruction Berbantuan Alat Peraga Pada Materi Cahaya Di SMP. Jurnal Pendidikan Fisika Indonesia 7(1).

Hartati, B (2010). Pengembangan Alat Peraga Gaya Gesek Untuk Meningkatkan Keterampilan Berpikir Kritis Siswa SMA. Jurnal Pendidikan Fisika Indonesia 6(2).

Hasan Qodri Ali (2012). Pengembangan Pembelajaran Operasi Pembagian Dengan Menekankan Aspek Pemahaman. In UNY: Prosiding Seminar Nasional Matematika dan Pendidkan Matematika FMIPA UNY Yogyakarta 10.

Henulili Victoria, Tien Aminatun, dan Wita Setianingsih (2009). Pelatihan Pembuatan Media Pembelajaran Biologi Berbasis Internet Bagi Guru Biologi SMA Di Kabupaten Sleman. Inotek, 13(2).

Imansnuna Luluk, Ulfi Faizah dan Ahmad Qosyim (2016). Pengembangan Alat Peraga Circulatori Bottle Untuk Meningkatkan Pemahaman Konsep Siswa Kela VIII SMP Pada Materi Sistttem Peredddaran Darah Manusia. Pendidkan Sains 4(2)

Manzilatusita, U (2007). Pemberian Motivasi Guru Dalam Pembelajaran. Jurnal Pendidikan dan Budaya Educare 5(1)

Nomleni Fransina TH. dan James E. Merukh (2014). Pengaruh Penggunaan Alat Peraga Dari Bahan Bekas Tentang System Eredaran Darah Manusia Terhadap Hasil Belajar Biologi Siswa Kelas XI SMAN 7 Kota Kupang Tahun Ajaran 2014/2015. Bioedukasi 7(2).

Putriani Deska and Chika Rahayu (2018). "The Effect Discovery Learning Model Using Sun Flowers In Circles on Mathematics Learnng Outcomes", International Journal of Trends in Mathematics Education Research 1(1)

Saleh Husnul Inayah, Nurhayati B, dan Oslan Jamadi (2015). Pengaruh Penggunaan Media Alat Peraga Terhadap Hasil belajar Siswa Pada Materi Sistem Peredaran Darah Kelas VIII SM Negeri 2 Bulukumba. Jurnal Sainsmat 4(3).

Sanjaya Wina (2006). Strategi Pembelajaran: Berorientasi Standar Proses Pendidikan. Jakarta: Prenada Media Group.

Sudijono Anas (2009). Pengantar Evaluasi Pendidikan. Jakarta: Rajawali Pers.

Sumantri, Mohamad, Syarif (2015). Strategi Pembelajaran: Teori dan Praktik di Tingkat Pendidikan Dasar. Jakarta: PT RajaGrafindo Persada.

Syarah, Sitti (2016). Penggunaan Media Model Sirkulasi Darah Dapat Meningkatkan Motivasi dan Hasil Belajar Siswa Kelas VIII-B SMPN 2 Bolo. Jurnal Pendidikan MIPA 6(2).

Winarno M. E (2011). Metodologi Penelitian Dalam Pendidikan Jasmani. Malang: UM Press. 